\title{
Quinolines: Microwave-assisted synthesis and their antifungal, anticancer and radical scavenger properties
}

\author{
Natália Aparecida Liberto a , Juliana Baptista Simões ${ }^{a}$, Sarah de Paiva Silva ${ }^{a}$, Cristiane Jovelina da Silva ${ }^{\mathrm{b}}$,

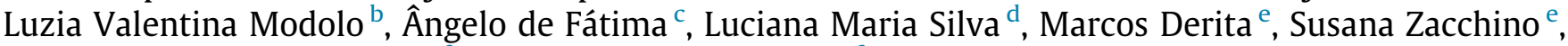 \\ Omar Miguel Portilla Zuñiga ${ }^{\mathrm{f}}$, Gustavo Pablo Romanelli ${ }^{\mathrm{f}}$, Sergio Antonio Fernandes ${ }^{\mathrm{a}, *}$ \\ ${ }^{a}$ Grupo de Química Supramolecular e Biomimética (GQSB), Departamento de Química, Universidade Federal de Viçosa, Viçosa, MG 36570-900, Brazil \\ ${ }^{\mathrm{b}}$ Grupo de Estudos em Bioquímica de Plantas (GEBioPlan), Departamento de Botânica, Instituto de Ciências Biológicas, Universidade Federal de Minas Gerais, Belo Horizonte, \\ MG 31270-901, Brazil \\ ${ }^{\mathrm{C}}$ Grupo de Estudos em Química Orgânica e Biológica (GEQOB), Departamento de Química, ICEx, Universidade Federal de Minas Gerais, Belo Horizonte, MG 31270-901, Brazil \\ d Laboratório de Biologia Celular, Fundação Ezequiel Dias, Belo Horizonte, MG, Brazil \\ e Farmacognosia, Facultad de Ciencias Bioquimicas y Farmacuticas, Universidad Nacional de Rosario, Argentina \\ ${ }^{\mathrm{f}}$ Centro de Investigación y Desarrollo en Ciencias Aplicadas 'Dr. Jorge J. Ronco' (CINDECA-CONICET-CCT-La Plata), Universidad Nacional de La Plata, Calle 47 No. 257, \\ B1900AJK La Plata, Argentina
}

\section{A R T I C L E I N F O}

\section{Article history:}

Received 21 September 2016

Revised 12 December 2016

Accepted 19 December 2016

Available online 21 December 2016

\begin{abstract}
A B S T R A C T
An efficient method for the synthesis of quinolines using microwave irradiation was developed providing 28 quinolines with good yields. The reaction procedures are environmentally friendly, convenient, mild and of easy work-up. Quinolines were evaluated for their antifungal, anticancer and antioxidant properties and exhibited high activities in all tests performed.
\end{abstract}

(c) 2016 Elsevier Ltd. All rights reserved.

Keywords:

Quinoline

Antifungal

Anticancer

Antioxidant

Calix $[n]$ arenes

\section{Introduction}

The quinolinic core is repeatedly found in various natural and synthetic products, including several important clinically used drugs and pharmaceutical candidates. ${ }^{1}$ Some 2,4-disubstituted quinolines have been reported as anti-tuberculosis ${ }^{2}$ and anthelmintic $^{3}$ agents and also effective for the treatment of leishmaniasis, a protozoan disease widespread in tropical areas of South America. ${ }^{4}$ Functionalized aminoquinolines ${ }^{5}$ and 2-heteroarylquinolines ${ }^{6}$ have been reported as potential antifungal agents. Synthesized amido and ureido quinoline derivatives substituted with 2-N-methylamido-pyridin-4-yloxy group effectively inhibited the proliferation of renal carcinoma, ovarian and lung cancer cells with potency higher than that of sorafenib, a reference drug. ${ }^{7}$ Diarylureas containing a 4-aryl-8-amino(acetamido)quinoline moiety are notable for their activities against melanoma cells as they exhibited concentration necessary to inhibit cell prolifera-

\footnotetext{
* Corresponding author.

E-mail addresses: santonio@ufv.br, sefernandes@gmail.com (S.A. Fernandes).
}

tion by $50 \%\left(\mathrm{IC}_{50}\right)$ in the order of nanomolar. ${ }^{8}$ Some quinoline hybrids with chalcogenide ${ }^{9}$, ferrocene ${ }^{10}$ or coumarins ${ }^{11}$ were shown to be good antioxidants.

Due to the broad range of applications in medicinal, industrial and bioorganic processes and in the synthetic organic chemistry area, there has been an increasing interest in developing efficient methods for the synthesis of quinolines. A variety of synthetic methods have been developed for obtaining 2,4-disubstituted quinolines, ${ }^{12}$ in which the three-component Povarov reaction ${ }^{13}$ has been proved to be the most empowering and versatile approach. Indeed, the three-component Povarov reaction is as convenient as the classical synthesis for this purpose in terms of efficacy, speed and atom economy. Then, the Povarov reaction, based on an inverse electron-demand aza-Diels-Alder reaction between an aniline, aldehyde and an electron-rich alkene to afford a tetrahydroquinoline, quinoline or julolidine, has long attracted the interest of synthetic chemists. This three-component reaction is reported to be catalyzed by $\mathrm{BF}_{3} / \mathrm{Et}_{2} \mathrm{O},{ }^{14}$ lanthanide(III) triflates, ${ }^{15}$ molecular iodine, ${ }^{16} \mathrm{SnCl}_{2},{ }^{17} \mathrm{TMSCl}^{18}$ TEMPO salt $\left(\mathrm{T}^{+} \mathrm{BF}_{4}^{-}\right){ }^{19}$ fluorinated alcohols, ${ }^{20} \mathrm{AG}^{\circledR} 50 \mathrm{~W}-\mathrm{X} 2$ resin, ${ }^{21}$ cellulose sulphuric 
acid $^{22}$ and triphenylmethylium cation. ${ }^{23}$ Our group and others have used calix[ $n$ ]arenes as organocatalysts in multicomponent reactions (MRCs), ${ }^{24}$ including a Povarov reaction designed for the synthesis of julolidines. ${ }^{25}$ Recently, we have reported the direct synthesis of 2,4-disubstituted quinolines using the Povarov reaction among anilines, benzaldehyde and styrene followed by in situ oxidation assisted by the catalyst $p$-sulfonic acid calix[4] arene $\left(\mathrm{CX}_{4} \mathrm{SO}_{3} \mathrm{H}\right) .{ }^{13 \mathrm{a}}$ Despite the good yields obtained from a single step reaction (38-71\%), the formation of 2,4-disubstituted quinolines occurred after long periods of reaction incubation $(12 \mathrm{~h})$ in the presence of acetonitrile as the solvent.

Microwave-assisted organic synthesis has become an interesting tool in organic synthesis for obtaining desired products from environmentally-friendly reactions based on the use of catalysts and free of solvents. Atom-economical processes have collectively contributed to promote the school of modern synthesis. ${ }^{26}$ To the best of our knowledge, the use of microwave irradiation to promote the Povarov reaction is still underexplored. ${ }^{27}$ Additionally, the design of an efficient and green approach based on the application of a reusable catalyst for the synthesis of 2,4-disubstituted quinolines is of great interest.

In this work, we investigated a simple and efficient protocol for the microwave-assisted synthesis of a series of 2,4-disubstituted quinolines under solvent-free conditions, with potential to inhibit the growth of fungal of clinical interest and proliferation of cancer cells and to scavenge free radicals.

\section{Results and discussion}

\subsection{Synthesis of quinolines}

A series of solvents as well as solvent-free conditions (Table 1) were tested to determine the best condition for obtaining quinolones in good yields. For this purpose, a model reaction constituted of 4-bromoaniline (1a), benzaldehyde (2a) and styrene (3) was chosen and carried out in the presence of $p$-sulfonic acid calix[4] arene $\left(\mathrm{CX} 4 \mathrm{SO}_{3} \mathrm{H}\right)$ as catalyst ( $\left.1 \mathrm{~mol} \%\right)$ under microwave irradiation. The use of ethanol or water as protic solvents yielded the quinoline Q1 in only 8\% and 5\%, respectively, in which the imine I1 was isolated as the major product (up to $27 \%$ yield) and the amine $\mathbf{A 1}$ in up to $15 \%$ yield, respectively (Table 1 , entries 1 and 2 ).
The $\mathbf{Q 1}$ was also obtained in low yield when aprotic solvents, such as acetonitrile or dichloromethane were used, conditions that yielded $\mathbf{I 1}$ in almost 50\% and $\mathbf{A 1}$ in 12\% in reactions performed with the former solvent (Table 1, entries 3 and 4). Under solvent-free conditions, the quinoline $\mathbf{Q 1}$ was isolated in $64 \%$ yield along with imine I1 in 20\% yield. Once determined that a solvent-free reaction was the best condition to obtain $\mathbf{Q 1}$, we further investigated the minimum amount of catalyst $\left(\mathrm{CX}_{4} \mathrm{SO}_{3} \mathrm{H}\right)$ required to achieve the maximum reaction yield. The $\mathbf{Q 1}$ yield decreased to $43 \%$ when the amount of $\mathrm{CX}_{4} \mathrm{SO}_{3} \mathrm{H}$ was diminished from $1.0 \mathrm{~mol} \%$ to $0.5 \mathrm{~mol} \%$ (Table 1 , entry 6 ). No further yield increment was achieved when the concentration of $\mathrm{CX}_{4} \mathrm{SO}_{3} \mathrm{H}$ was increased from 1 to $2 \mathrm{~mol} \%$ (Table 1 , entry 7 ). The use of $\mathrm{CX}_{4} \mathrm{SO}_{3} \mathrm{H}$ at $5 \mathrm{~mol} \%$ provided $\mathbf{Q 1}$ at 58\% (Table 1, entry 8). No detectable amount of $\mathbf{Q 1}$ was observed in reaction devoid of catalyst, a condition that yielded the imine I1 at 30\% (Table 1, entry 9). Overall, the use of solvent-free conditions and $1 \mathrm{~mol} \% \mathrm{CX}_{4} \mathrm{SO}_{3} \mathrm{H}$ as catalyst provided the highest Q1 yield (64\%) from Povarov reaction in which 20\% of the substrate aniline was converted to some byproducts (Table 1 , entry 5 ).

By using the optimal reaction conditions, it was found that the incubation of reactions at 150,200 or $250{ }^{\circ} \mathrm{C}$ for 5 or $10 \mathrm{~min}$ yielded undetectable amounts of $\mathbf{Q 1}$ (Table 2, entries 1-6). Similar results was achieved when reaction were incubated at $150{ }^{\circ} \mathrm{C}$ for 15 min (Table 2, entry 7). The $\mathbf{Q 1}$ yield of up to $35 \%$ was verified from incubation of reactions at 200 to $250^{\circ} \mathrm{C}$ for $15 \mathrm{~min}$ (Table 2 , entries 8 and 9). Longer periods of reaction incubation (20-25 min) at the maximum temperature of $200^{\circ} \mathrm{C}$ provided the best yields for $\mathbf{Q 1}$ (Table 2, entries 11 and 14).

Notably, the highest yield was obtained for the model reaction carried out in an open vessel in the presence of $1 \mathrm{~mol} \% \mathrm{CX}_{4} \mathrm{SO}_{3} \mathrm{H}$, under acetonitrile for $12 \mathrm{~h}$ and oil bath $\left(80^{\circ} \mathrm{C}\right.$ ) (Table 2 , entry 16). ${ }^{13 a}$

Once determined the best mild conditions to synthesize quinolines from the Povarov reaction, we next examined the scope of this reaction by varying the aldehydes employed as shown in Fig. 1. The classical thermal method using acetonitrile under $12 \mathrm{~h}$ reflux $^{13 a}$ was adopted for obtaining Q1-Q28 for comparison purpose (Fig. 1).

With respect to the reactions using 4-bromoaniline, similar yields were observed for obtaining Q1-Q13 using either the conventional heating or microwave approaches regardless of the

Table 1

Optimization of the reaction conditions. ${ }^{a}$
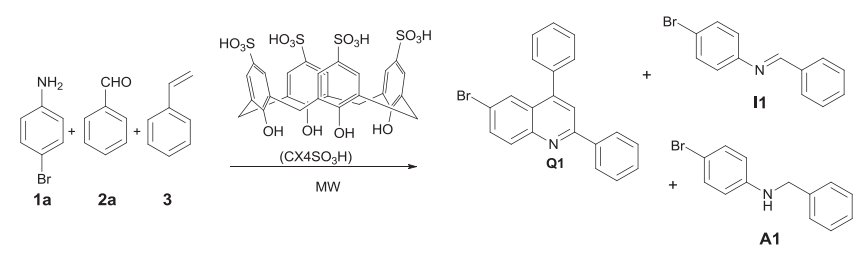

\begin{tabular}{|c|c|c|c|c|c|}
\hline Entry & Solvent & $\mathrm{CX}_{4} \mathrm{SO}_{3} \mathrm{H}(\mathrm{mol} \%)$ & Q1 yield $(\%)^{d}$ & I1 yield $(\%)^{\mathrm{d}}$ & A1 yield $(\%)^{d}$ \\
\hline 1 & Ethanol $^{\mathrm{b}}$ & 1.0 & 8 & 20 & 15 \\
\hline 2 & Water $^{\mathrm{b}}$ & 1.0 & 5 & 27 & 11 \\
\hline 3 & Acetonitrile $^{\mathrm{b}}$ & 1.0 & 15 & 13 & 12 \\
\hline 4 & $\mathrm{DCM}^{\mathrm{b}}$ & 1.0 & 15 & 47 & - \\
\hline 5 & None $^{c}$ & 1.0 & 64 & 20 & - \\
\hline 6 & None $^{c}$ & 0.5 & 43 & 15 & - \\
\hline 7 & None $^{\mathrm{c}}$ & 2.0 & 65 & 16 & - \\
\hline 8 & None $^{c}$ & 5.0 & 58 & 17 & - \\
\hline 9 & None $^{c}$ & 0.0 & 0.0 & 30 & 20 \\
\hline
\end{tabular}

${ }^{\text {a }}$ Reagents and conditions: 4-bromoaniline $\mathbf{1 a}(1.0 \mathrm{mmol})$, benzaldehyde $\mathbf{2 a}(1.2 \mathrm{mmol})$ and styrene $\mathbf{3}$ (1.5 mmol) for $20 \mathrm{~min}$ under power of $50 \mathrm{~W}$ in a sealed tube.

b Under reflux.

c Reactions at $200^{\circ} \mathrm{C}$

d Isolated yield. DCM, dichloromethane. 
Table 2

Effect of temperature and incubation time on the production of quinolines. ${ }^{a}$

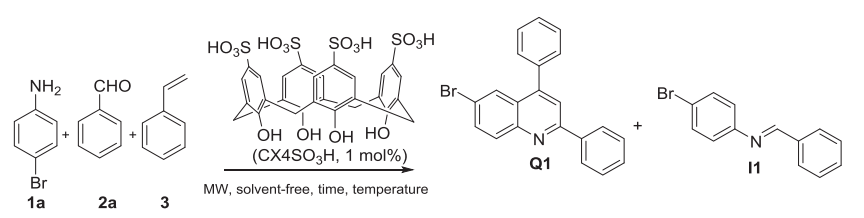

\begin{tabular}{|c|c|c|c|c|}
\hline Entry & Temperature $\left({ }^{\circ} \mathrm{C}\right)$ & Time (min) & Yield Q1 (\%) & Yield I1 (\%) \\
\hline 1 & 150 & 5 & - & 20 \\
\hline 2 & 200 & 5 & - & 24 \\
\hline 3 & 250 & 5 & - & 29 \\
\hline 4 & 150 & 10 & - & 33 \\
\hline 5 & 200 & 10 & - & 45 \\
\hline 6 & 250 & 10 & - & 44 \\
\hline 7 & 150 & 15 & - & 36 \\
\hline 8 & 200 & 15 & 30 & 30 \\
\hline 9 & 250 & 15 & 35 & 20 \\
\hline 10 & 150 & 20 & 24 & 47 \\
\hline 11 & 200 & 20 & 64 & 20 \\
\hline 12 & 250 & 20 & 38 & 34 \\
\hline 13 & 150 & 25 & 26 & 45 \\
\hline 14 & 200 & 25 & 65 & 16 \\
\hline 15 & 250 & 25 & 42 & 26 \\
\hline $16^{\mathrm{c}}$ & 80 & 720 & 65 & 13 \\
\hline
\end{tabular}

${ }^{a}$ Reagents and conditions: 4-bromoaniline/benzaldehyde/styrene (molar ratio of 1.0;1.2;1.5) in sealed tube.

b Isolated yield.

c Conventional heating $\left(80^{\circ} \mathrm{C}\right)$ in the presence of acetonitrile.

aldehyde employed. However, the use of aromatic aldehydes bearing $-\mathrm{OH}$ or $-\mathrm{NO}_{2}$ provided the corresponding quinoline in poor yields ( $<20 \%$ ). Additionally, cyclohexanecarboxaldehyde furnished the corresponding quinoline $(\mathbf{Q 7})$ in yields equal to or lower than $35 \%$ (Fig. 1).

The use of microwave irradiation and different aniline substrates led to the formation of quinolines in better yields as attested by the results obtained for the synthesis of Q14-Q28 (Fig. 1). Indeed, the microwave irradiation was determined to be in the range from $11 \%$ to $19 \%$ more efficient than conventional heating for obtaining the quinolines $\mathbf{Q 1 6}, \mathbf{Q 1 8}, \mathbf{Q 2 1}$ and $\mathbf{Q 2 5}$ while the yield of $\mathbf{Q 2 6}$ using the former approach was twice as higher as that of the latter ones (Fig. 1). Reactions under microwave irradiation furnished the desired quinolines more rapidly when compared with those under thermal heating and solvent-free conditions.

The mechanism that drives Povarov reaction is still under debate, in which the most widely accepted one involves a stepwise sequence via ionic intermediates generated by a Mannich-like reaction, followed by an intramolecular electrophilic aromatic substitution. ${ }^{28}$ Based on this, a mechanism for the formation of the functionalized quinolines herein described is hypothesized in Scheme 1. The first step consists of the reaction between aniline and the activated aldehyde to provide the iminium via Mannich reaction. The reaction with iminium, after styrene addition, forms the corresponding carbocation. Then, an intramolecular electrophilic aromatic substitution takes place to furnish the tetrahydroquinoline, which is further oxidized to the corresponding quinoline.

The ion exchange capacity of the catalyst was determined by acid-base titration ${ }^{29}$ using $5 \mathrm{mM} \mathrm{NaOH}$ (aq). A total of $8.6 \mathrm{mmol}$ of $\mathrm{H}^{+} \mathrm{g}^{-1}$ were necessary to completely titrate $\mathrm{CX} 4 \mathrm{SO}_{3} \mathrm{H}$. This result is consistent as the catalyst bears eight strong acid sites (four $-\mathrm{SO}_{3} \mathrm{H}$ and four $-\mathrm{OH}$ groups).

The potential of $\mathrm{CX}_{4} \mathrm{SO}_{3} \mathrm{H}$ to be reused in the reaction to obtain quinolines was also investigated. The $\mathrm{CX}_{4} \mathrm{SO}_{3} \mathrm{H}$ could be successfully used up to five successive reactions without significant loss of catalytic power (Fig. 2). The catalyst was easily recovered from the reaction by liquid-liquid extraction with water and dichloromethane followed by evaporation of aqueous phase under reduced pressure. As a result, the reaction model constituted of 4-bromoaniline (1a), benzaldehyde (2) and styrene (3) could still afford quinoline $\mathbf{Q 1}$ in good yield even after five cycles (Fig. 2).

\subsection{Antifungal activities}

Because of the need to develop new structures with antifungal activity $^{30}$ and considering that other quinoline-bearing structures have shown promising antifungal activities, ${ }^{31}$ the 2,4 -disubstituted quinolines synthesized were tested against some fungi of clinical interest such as Candida albicans and Cryptococcus neoformans. The $C$. albicans is the etiological agent of many opportunistic infections in immunocompromised hosts ${ }^{32}$ while $C$. neoformans causes cryptococcal meningitis, one of the most important HIV-related fatal opportunistic mycosis that has killed to date over 650,000 immunocompromised patients worldwide. $^{30 c}$ Although the incidence of HIV tends to decrease in countries with highly active anti-retroviral therapy, fungal infections remain a serious problem for AIDS patients. As a consequence, the design of compounds with anti-cryptococcal activity is very desirable. ${ }^{33}$

To better understand the results of MIC values for inhibition of fungal growth, the quinolines synthesized were divided into three categories: (i) group I, comprised the non-substituted or 2-position-substituted benzene ring quinolines; (ii) group II represented by $\mathbf{Q 7}$ that bears a 2-cyclohexyl ring and (iii) represented by $\mathbf{Q 1 3}$ that bears a 2-furyl substituent at 2-position of the quinoline ring (Table 3). Group I was further subdivided in I.1, in which were grouped quinolines (Q1-Q6 and $\mathbf{Q 8 - Q 1 2})$ that possess a - Br substituent at 6-position $\left(R_{2}\right)$ of quinoline skeleton and a variety of substitution at 2-position $\left(R_{4}, R_{5}\right.$ and/or $\left.R_{6}\right)$ of the benzene ring. The subgroup I.2, on the other hand, includes compounds (Q14Q28) that present a phenyl group at 2-position of the quinoline ring with a variety of substituents at positions $5\left(R_{1}\right), 6\left(R_{2}\right)$ and $7\left(R_{3}\right)$ of this same core. 


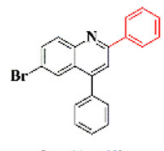

$\mathrm{Q}=61$ or $65 \%$

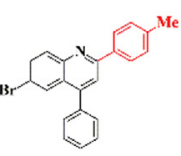

$Q 5=57$ or $54 \%$

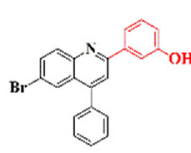

Q9- 19 or 174\%



Q13= 64 of $619 \%$

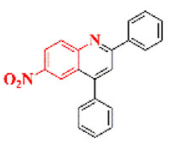

Q17- 53 or $45 \%$

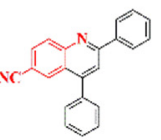

$021=59$ or $40 \%$

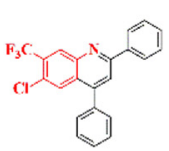

Q $25=77$ or $52 \%$
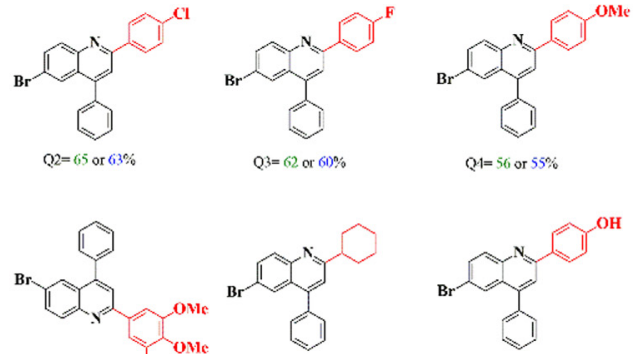

$Q 6=56$ or $55 \%$

Q7- 35 or $34 \%$

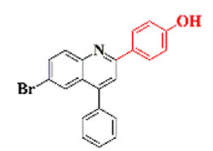

Q $=12$ or $11 \%$

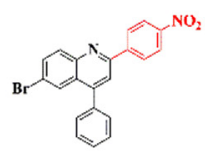

Q10- 12 or $10 \%$



Q11- 18 or $13 \%$
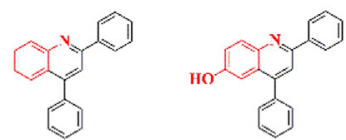

Q14 $=40$ or $38 \%$

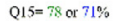

$\mathrm{Q} 15=38$ or $71 \%$

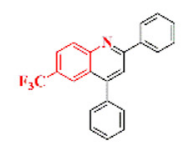

Q18 69 or $55 \%$
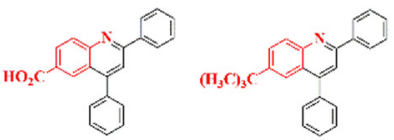

Q22- 51 or $43 \%$

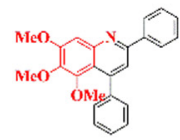

Q26 $=81$ or $40 \%$

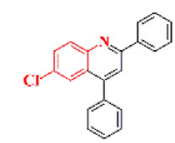

Q19- 65 or $68 \%$

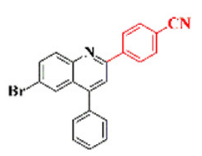

Q12-62 or $60 \%$

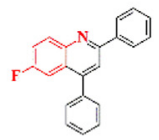

$Q 16=71$ or $60 \%$

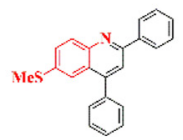

Q20-65 or $64 \%$

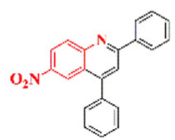

Q24-62 or $60 \%$

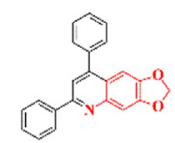

$Q 27=70$ or $61 \%$

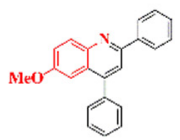

$028=64$ or $600^{\circ} \%$
Fig. 1. Synthesis of 2,4-disubstituted quinolines employing $\mathrm{CX}_{4} \mathrm{SO}_{3} \mathrm{H}$ as catalyst. Yields in green were obtained by microware (MW) and yields in blue were obtained by conventional heating $(\mathrm{CH})$. MW: $200^{\circ} \mathrm{C}, 20 \mathrm{~min}$, solvent-free. $\mathrm{CH}: 80^{\circ} \mathrm{C}$, acetonitrile, 12 h. Q14-Q28 synthesis by Simões et al., $2014{ }^{13 a}$

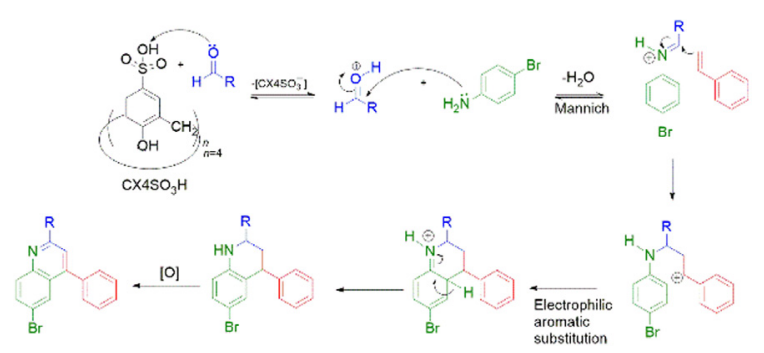

Scheme 1. Mechanistic proposal for the synthesis of quinolines from Povarov reaction.

The $\mathrm{MIC}_{80}$ and $\mathrm{MIC}_{50}$ values shown in Fig. 3 were determined from experiments of fungal growth inhibition in the presence of quinolines or amphotericin B (Amph B; reference drug) in the range from 3.9 to $250 \mu \mathrm{g} \mathrm{mL}^{-1}$ (Table S1; Supplementary material). The $\mathrm{MIC}_{80}$ and $\mathrm{MIC}_{50}$ values correspond to the minimum

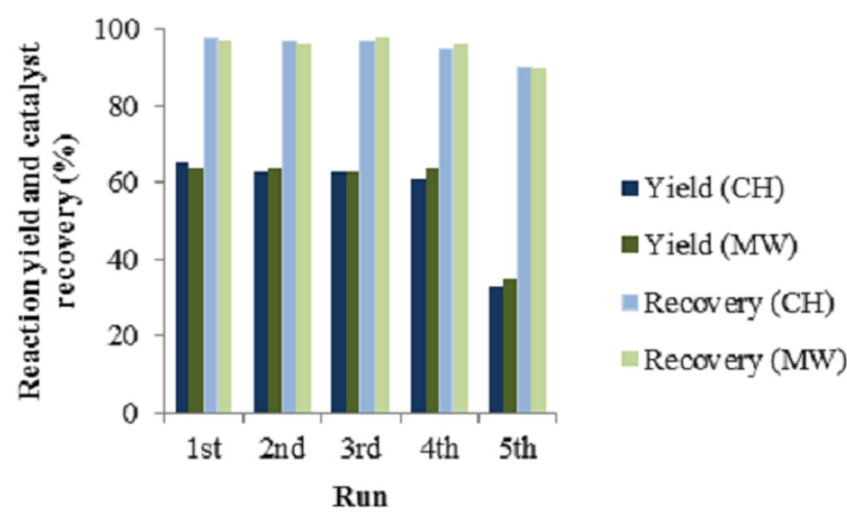

Fig. 2. Recovery and potential of $\mathrm{CX}_{4} \mathrm{SO}_{3} \mathrm{H}$ to be reused as catalyst in Povarov reaction for the synthesis of 2,4-disubstituted quinolines. MW, microwave heating and $\mathrm{CH}$, conventional heating.

concentration of a compound-test necessary to inhibit the fungus growth by $80 \%$ and $50 \%$, respectively. Such values are well accepted in the literature as representative of the in vitro activity of target compounds. $^{34}$

Quinolines Q1-Q3, Q6-Q8, Q13-Q28 inhibited C. albicans or/and $C$. neoformans growth at different extents (Table 3). The C. neoformans, however, was shown to be more sensitive to the quinolines tested $\left(\mathrm{MIC}_{50}\right.$ values lower than $250 \mu \mathrm{g} \mathrm{mL}^{-1}$ ) than did C. albicans.

To determine the influence of the substituent at 2-position of the quinoline ring, we evaluated the percentage of growth inhibition towards $C$. albicans or $C$. neoformans as a function of the concentration of Q1, Q7 and Q13. The quinoline bearing a furan ring at 2-position (Q13) effectively inhibited the growth of both fungi tested acting in a concentration-dependent mode on C. neoformans and exhibiting maximum inhibitory effect (78\%) on C. albicans when used at $125 \mu \mathrm{g} \mathrm{mL}^{-1}$ (Fig. 3). A maximum growth inhibition of around 55\% was achieved from $C$. albicans incubation with $62.5 \mu \mathrm{g} \mathrm{mL}^{-1} \mathbf{Q 1}$ (bearing a 2-phenyl group) while a much higher concentration (4-fold) of this same quinoline was required to have similar effect on $C$. neoformans. The $\mathbf{Q 7}$, which bears a cyclohexyl at 2-position, was the least effective against $C$. albicans and C. neoformans (Fig. 3). Overall, the presence of a heteroaromatic ring at 2-position of quinolic ring boosts the antifungal activity of quinolines.

When considering all the other quinolines synthesized, almost all compounds belonging to the subgroup I.1 were determined to be poor antifungals against $C$. albicans. On the other hand, some of them exhibited relatively low $\mathrm{MIC}_{50}$ values activity against $C$. neoformans. Indeed, the most active compounds ( $\mathrm{MIC}_{50}$ values lower than $16 \mu \mathrm{g} \mathrm{mL}^{-1}$ ) possess $-\mathrm{F}(\mathbf{Q 3})$ or $-\mathrm{CH}_{3}(\mathbf{Q 5})$ as $\mathrm{R}_{5}$ group (Table 3). Compound $\mathbf{Q 6}$, which presents a $-p-\mathrm{OCH}_{3}$ as $\mathrm{R}_{5}$ group and two other $-\mathrm{OCH}_{3}$ groups as $\mathrm{R}_{4}$ and $\mathrm{R}_{6}$, exhibited moderate activity $\left(\mathrm{MIC}_{50}\right.$ lower than $65.0 \mu \mathrm{g} \mathrm{mL}^{-1}$ ). Notably, the presence of $-\mathrm{Cl},-\mathrm{OCH}_{3},-\mathrm{NO}_{2}$, and $-\mathrm{CN}$ as $\mathrm{R}_{5}$ group and $-\mathrm{NO}_{2}$ as $\mathrm{R}_{6}$ group negatively affected the activity of quinolines as attested by the results of MIC values obtained for Q2, Q4, Q10, Q11 and Q12 (Table 3). On the other hand, compounds belonging to subgroup I.2 that bear $-\mathrm{NO}_{2}$ or $-\mathrm{CF}_{3}$ groups, either at $6-\left(\mathrm{R}_{2} ; \mathbf{Q 1 7}\right)$ or 7 -position $\left(\mathrm{R}_{3} ; \mathbf{Q 2 4}\right)$ presented similar effects on $C$. neoformans (Table 3 ). Quinolines presenting $-\mathrm{Cl},-\mathrm{SCH}_{3},-\mathrm{C}\left(\mathrm{CH}_{3}\right)_{3},-\mathrm{OCH}_{2} \mathrm{O}$ or $-\mathrm{OCH}_{3}$ at 6-position ( $\mathbf{Q 1 9}, \mathbf{Q 2 0}, \mathbf{Q 2 3}, \mathbf{Q 2 6}, \mathbf{Q 2 7}$ and $\mathbf{Q 2 8}$ ) were very active against $C$. neoformans. Compound $\mathbf{Q 2 6}$ was also identified as the only effective against $C$. albicans (Table 3 ). The presence of $-\mathrm{OH}$ at 7-position (Q14) enhances 8-fold the antifungal activity against C. neoformans when compared with a non-substituted quinoline at similar position (Q15). 
Table 3

Effect of quinolines on the growth of Candida albicans ATCC 10231 and Cryptococcus neoformans ATCC 32264.
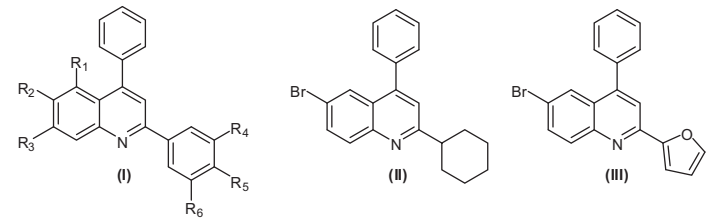

\begin{tabular}{|c|c|c|c|c|c|c|c|c|c|c|c|}
\hline \multirow[t]{2}{*}{ Compounds } & \multirow[t]{2}{*}{ Category } & \multirow[t]{2}{*}{$\mathrm{R}_{1}$} & \multirow[t]{2}{*}{$\mathrm{R}_{2}$} & \multirow[t]{2}{*}{$\mathrm{R}_{3}$} & \multirow[t]{2}{*}{$\mathrm{R}_{4}$} & \multirow[t]{2}{*}{$\mathrm{R}_{5}$} & \multirow[t]{2}{*}{$\mathrm{R}_{6}$} & \multicolumn{2}{|c|}{ C. albicans } & \multicolumn{2}{|c|}{ C. neoformans } \\
\hline & & & & & & & & $\mathrm{MIC}_{80}$ & $\mathrm{MIC}_{50}$ & $\mathrm{MIC}_{80}$ & $\mathrm{MIC}_{50}$ \\
\hline Q1 & $\mathrm{I} .1$ & $\mathrm{H}$ & $\mathrm{Br}$ & $\mathrm{H}$ & $\mathrm{H}$ & $\mathrm{H}$ & $\mathrm{H}$ & $>250.0$ & 125.0 & $>250.0$ & 31.2 \\
\hline $\mathbf{Q 2}$ & & $\mathrm{H}$ & $\mathrm{Br}$ & $\mathrm{H}$ & $\mathrm{H}$ & $\mathrm{Cl}$ & $\mathrm{H}$ & $>250.0$ & 250.0 & $>250.0$ & 250.0 \\
\hline Q3 & & $\mathrm{H}$ & $\mathrm{Br}$ & $\mathrm{H}$ & $\mathrm{H}$ & $\mathrm{F}$ & $\mathrm{H}$ & $>250.0$ & $>250.0$ & $>250.0$ & 15.6 \\
\hline Q4 & & $\mathrm{H}$ & $\mathrm{Br}$ & $\mathrm{H}$ & $\mathrm{H}$ & OMe & $\mathrm{H}$ & $>250.0$ & $>250.0$ & $>250.0$ & $>250.0$ \\
\hline Q5 & & $\mathrm{H}$ & $\mathrm{Br}$ & $\mathrm{H}$ & $\mathrm{H}$ & $\mathrm{Me}$ & $\mathrm{H}$ & $>250.0$ & $>250.0$ & $>250.0$ & 15.6 \\
\hline Q6 & & $\mathrm{H}$ & $\mathrm{Br}$ & $\mathrm{H}$ & $\mathrm{OCH}_{3}$ & $\mathrm{OCH}_{3}$ & $\mathrm{OCH}_{3}$ & 250.0 & 125.0 & 250.0 & 62.5 \\
\hline Q8 & & $\mathrm{H}$ & $\mathrm{Br}$ & $\mathrm{H}$ & $\mathrm{H}$ & $\mathrm{OH}$ & $\mathrm{H}$ & 125.0 & 62.5 & 250.0 & 62.5 \\
\hline Q9 & & $\mathrm{H}$ & $\mathrm{Br}$ & $\mathrm{H}$ & $\mathrm{H}$ & $\mathrm{H}$ & $\mathrm{OH}$ & $>250.0$ & $>250.0$ & $>250.0$ & $>250.0$ \\
\hline Q10 & & $\mathrm{H}$ & $\mathrm{Br}$ & $\mathrm{H}$ & $\mathrm{H}$ & $\mathrm{NO}_{2}$ & $\mathrm{H}$ & $>250.0$ & $>250.0$ & $>250.0$ & $>250.0$ \\
\hline Q11 & & $\mathrm{H}$ & $\mathrm{Br}$ & $\mathrm{H}$ & $\mathrm{H}$ & $\mathrm{H}$ & $\mathrm{NO}_{2}$ & $>250.0$ & $>250.0$ & $>250.0$ & $>250.0$ \\
\hline Q12 & & $\mathrm{H}$ & $\mathrm{Br}$ & $\mathrm{H}$ & $\mathrm{H}$ & $\mathrm{CN}$ & $\mathrm{H}$ & $>250.0$ & $>250.0$ & $>250.0$ & $>250.0$ \\
\hline Q14 & $\mathrm{I} .2$ & $\mathrm{H}$ & $\mathrm{H}$ & $\mathrm{OH}$ & $\mathrm{H}$ & $\mathrm{H}$ & $\mathrm{H}$ & $>250.0$ & $>250.0$ & $>250.0$ & 15.6 \\
\hline Q15 & & $\mathrm{H}$ & $\mathrm{OH}$ & $\mathrm{H}$ & $\mathrm{H}$ & $\mathrm{H}$ & $\mathrm{H}$ & $>250.0$ & 250.0 & 250.0 & 125.0 \\
\hline Q16 & & $\mathrm{H}$ & $\mathrm{F}$ & $\mathrm{H}$ & $\mathrm{H}$ & $\mathrm{H}$ & $\mathrm{H}$ & $>250.0$ & 250.0 & $>250.0$ & $>250.0$ \\
\hline Q17 & & $\mathrm{H}$ & $\mathrm{NO}_{2}$ & $\mathrm{H}$ & $\mathrm{H}$ & $\mathrm{H}$ & $\mathrm{H}$ & $>250.0$ & $>250.0$ & 250.0 & 125.0 \\
\hline Q18 & & $\mathrm{H}$ & $\mathrm{CF}_{3}$ & $\mathrm{H}$ & $\mathrm{H}$ & $\mathrm{H}$ & $\mathrm{H}$ & $>250.0$ & $>250.0$ & 250.0 & 250.0 \\
\hline Q19 & & $\mathrm{H}$ & $\mathrm{Cl}$ & $\mathrm{H}$ & $\mathrm{H}$ & $\mathrm{H}$ & $\mathrm{H}$ & $>250.0$ & $>250.0$ & $>250.0$ & 15.6 \\
\hline Q20 & & $\mathrm{H}$ & $\mathrm{SCH}_{3}$ & $\mathrm{H}$ & $\mathrm{H}$ & $\mathrm{H}$ & $\mathrm{H}$ & $>250.0$ & 250.0 & 31.2 & 15.6 \\
\hline Q21 & & $\mathrm{H}$ & $\mathrm{CN}$ & $\mathrm{H}$ & $\mathrm{H}$ & $\mathrm{H}$ & $\mathrm{H}$ & $>250.0$ & 250.0 & 250.0 & 125.0 \\
\hline Q22 & & $\mathrm{H}$ & $\mathrm{CO}_{2} \mathrm{H}$ & $\mathrm{H}$ & $\mathrm{H}$ & $\mathrm{H}$ & $\mathrm{H}$ & $>250.0$ & 250.0 & $>250.0$ & 250.0 \\
\hline Q23 & & $\mathrm{H}$ & $\mathrm{C}\left(\mathrm{CH}_{3}\right)_{3}$ & $\mathrm{H}$ & $\mathrm{H}$ & $\mathrm{H}$ & $\mathrm{H}$ & $>250.0$ & $>250.0$ & 15.6 & 3.9 \\
\hline Q24 & & $\mathrm{H}$ & $\mathrm{H}$ & $\mathrm{NO}_{2}$ & $\mathrm{H}$ & $\mathrm{H}$ & $\mathrm{H}$ & $>250.0$ & 250.0 & $>250.0$ & 125.0 \\
\hline Q25 & & $\mathrm{H}$ & $\mathrm{Cl}$ & $\mathrm{CF}_{3}$ & $\mathrm{H}$ & $\mathrm{H}$ & $\mathrm{H}$ & $>250.0$ & 250.0 & $>250.0$ & 250.0 \\
\hline Q26 & & $\mathrm{OCH}_{3}$ & $\mathrm{OCH}_{3}$ & $\mathrm{OCH}_{3}$ & $\mathrm{H}$ & $\mathrm{H}$ & $\mathrm{H}$ & 125.0 & 125.0 & 15.6 & 7.8 \\
\hline Q27 & & $\mathrm{H}$ & $\mathrm{OCH}_{2} \mathrm{O}$ & $\mathrm{H}$ & $\mathrm{H}$ & & $\mathrm{H}$ & $>250.0$ & $>250.0$ & 250.0 & 31.2 \\
\hline Q28 & & $\mathrm{H}$ & $\mathrm{OCH}_{3}$ & $\mathrm{H}$ & $\mathrm{H}$ & $\mathrm{H}$ & $\mathrm{H}$ & $>250.0$ & 250.0 & 250.0 & 31.2 \\
\hline Q7 & II & - & - & - & - & - & - & $>250.0$ & 250.0 & $>250.0$ & 250.0 \\
\hline Q13 & III & - & - & - & - & - & - & 125.0 & 62.5 & 250.0 & 62.5 \\
\hline Amph B & & & & & & & & 0.12 & 0.06 & 0.25 & 0.12 \\
\hline
\end{tabular}

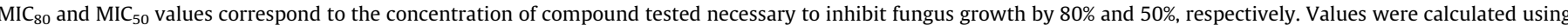

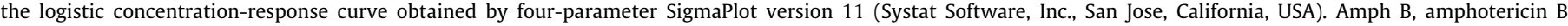
(reference drug).
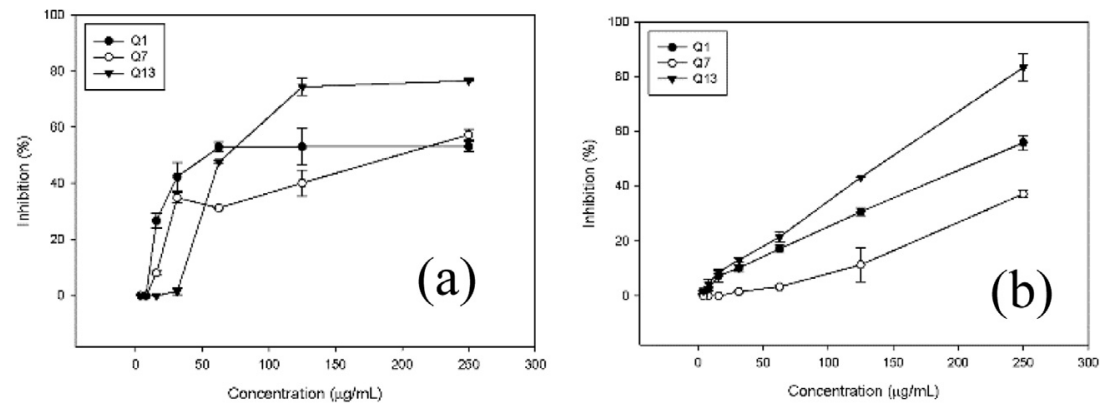

Fig. 3. Comparative antifungal activities of Q1, Q7 and Q13 against C. albicans ATCC 10231 (a) and C. neoformans ATCC 32264 (b).

Overall, $C$. neoformans was more susceptible than $C$. albicans to 2,4-disubstituted quinolines and their derivatives. The $\mathbf{Q 1 3}$ was the most active among the 2-substituted compounds (bearing -2-phenyl, 2-cyclohexyl or 2-furan) containing - $\mathrm{Br}$ at 6-position. Then, this opens an opportunity for the synthesis of a new series of potential antifungal quinolines bearing a furan ring. Within 6-brominated compounds (I.1 category), the most active were those solely substituted at the 2-phenyl group ( $\mathbf{Q} 3$ with $R_{5}=F$ and $\mathbf{Q 5}$ with $\mathrm{R}_{5}=\mathrm{CH}_{3}$ ). Likewise, the $3^{\prime}, 4^{\prime}, 5^{\prime}-\mathrm{OCH}_{3}$ derivative $(\mathbf{Q 6})$ was more active than the corresponding monosubstituted one (Q4).

\subsection{Antiproliferative assays}

Cell proliferation was determined using the MTT assay with absorbance measurements at $540 \mathrm{~nm}$. All synthesized quinolines (Q1-Q28) were evaluated in vitro against the following cancer cell lines: NCI-H226 (lung), TOV-21G (ovary) and Hep-2c (Hela contaminant). Compounds were also tested against a non-cancerous human cell line (CCD 19-Lu; lung fibroblast) to determine the selective index (SI). Data (Fig. 4) were submitted to Analysis of variance (ANOVA) one factor post-hoc analysis using the Least 


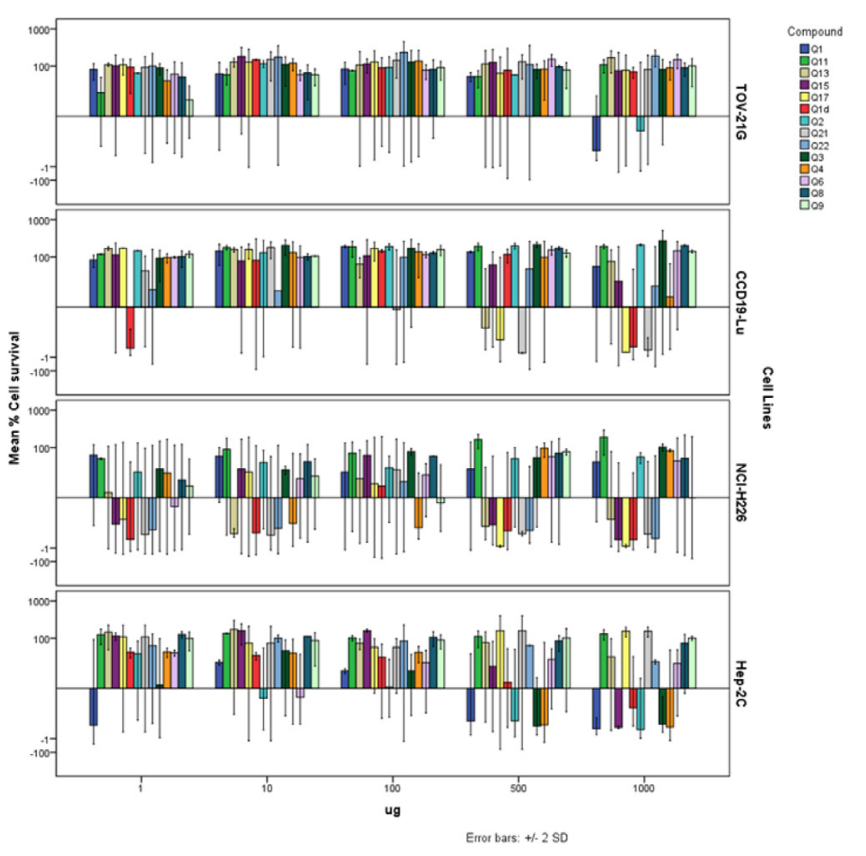

Fig. 4. Tumor and non-tumor cell survival after treatment with quinolines. The $y=0$ indicates the $50 \%$ survival limit, in which compounds furnishing values higher than zero show cytostatic effect while those providing values lower than zero are considered cytotoxic. Differences between groups were analyzed using a nonparametric test (Kruskal Wallis; $P<0.05$ ).

Significant Difference (LSD) method, which showed statistically difference only between the control and concentrations of 1000 and $1500 \mu \mathrm{g} \mathrm{mL}^{-1}$.

The concentrations of quinolines that caused cell growth inhibition by $50 \%$ ( $\mathrm{IC}_{50}$ values) and the selectivity indexes are summarized in Table 4 . The selectivity index compares the cytotoxicity of a compound against tumor cells and non-tumor cells. The calculation provides the ratio of $\mathrm{IC}_{50}$ value obtained for the non-tumor cell line to the $\mathrm{IC}_{50}$ value obtained for the tumor cell line. Regarding the analysis of selectivity ratios, there is no consensus in the literature on the threshold values for tumor cell lines. However, it was found that values greater than 5 are good indicators of selectivity. ${ }^{35}$

The IC 50 values indicated that Tov21G cells were more resistant and that NCI-H226 cells were more susceptible to all compounds tested (Fig. 5). According to the TP53 database of the International Agency of cancer (http://p53.iarc.fr/CellLines.aspx), the NCI-H226

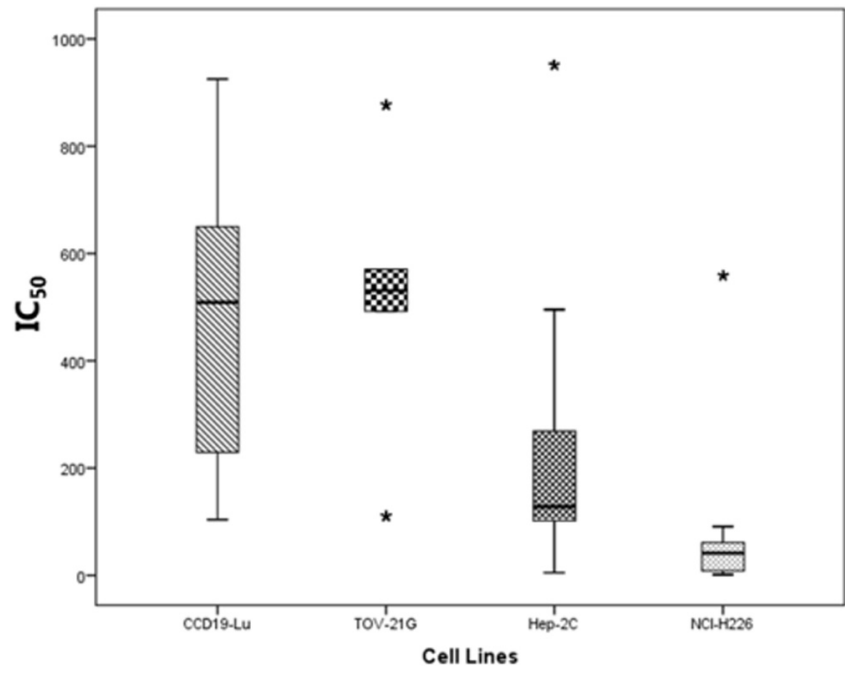

Fig. 5. Concentration of quinolines required to inhibit the proliferation of some tumor (Tov21G, Hep2 and NCI-H226) and non-tumor (CCD19-Lu) cells by 50\% $\left(\mathrm{IC}_{50}\right)$. Asterisks indicate significant difference by ANOVA post hoc LSD test $(P<0.05)$.

cell line is TP53 mutated while the TOV21G is wild-type. This mutation could explain the differences of cell survival observed for the tumor lines studied when incubated with quinolines, as TP53 gene encodes for a tumor suppressor protein that is responsible for regulating the expression of target genes related to DNA repair.

An examination of the association between survival and $\mathrm{IC}_{50}$ values highlighted the compounds that had the most promising antitumour activities (Fig. 6). The normal cell line CCD19-Lu proved to be most susceptible to cytotoxicity with quinolines Q7, Q8, Q27 and Q28, while all were cytotoxic for NCI-H226 cells (susceptible), and none were cytotoxic for TOV21G (resistant). The NCI-H226 line was selectively susceptible for the majority of quinolines and presented the best selective indices. The NCI-H226 line is an epithelial lung cancer derived from a metastatic site. It is one of the more aggressive cancer types with a high incidence and prevalence. These compounds proved at priori to be one good source of antitumoural molecules for lung cancer. The TOV21G cells (resistant) were selectively susceptible only to the Q1, Q3 and Q28 quinolines. The Tov 21G cell line is from an epithelial ovary cancer that is classified as aggressive. Thus, these compounds proved to be good agents for improving effectiveness

Table 4

Concentration of quinolines required to inhibit the proliferation of tumor cells by $50 \%\left(\mathrm{IC}_{50}\right)$ and respective selective index (SI).

\begin{tabular}{|c|c|c|c|c|c|c|c|}
\hline \multirow[b]{2}{*}{ Quinolines } & \multicolumn{4}{|l|}{$\mathrm{IC}_{50}(\mu \mathrm{M})$} & \multicolumn{3}{|l|}{ SI $(\mu \mathrm{M})$} \\
\hline & TOV-21G & CCD19-Lu & $\mathrm{NCI}-\mathrm{H} 226$ & Hep-2C & TOV-21G & $\mathrm{NCI}-\mathrm{H} 226$ & Hep-2C \\
\hline Q1 & 530.7 & 668.7 & 43.4 & 128.1 & 1 & 15 & 5 \\
\hline Q2 & ND & 528.1 & 1.58 & 269.0 & ND & 356 & 1 \\
\hline Q3 & 570.4 & ND & ND & 5.0 & ND & ND & ND \\
\hline Q5 & ND & ND & ND & 175.0 & ND & ND & ND \\
\hline Q6 & 492.6 & 104.5 & 61 & ND & 0 & 1 & ND \\
\hline Q7 & ND & 489.5 & 91 & ND & ND & 5 & ND \\
\hline Q8 & ND & 104.2 & 8 & 104.8 & ND & 13 & 0 \\
\hline Q11 & ND & ND & 8.5 & ND & ND & ND & ND \\
\hline Q12 & ND & ND & ND & 98.8 & ND & ND & ND \\
\hline Q13 & 876.8 & 631.1 & 30 & 101.8 & 0 & 21 & 6 \\
\hline Q14 & ND & ND & ND & ND & ND & ND & ND \\
\hline Q24 & ND & ND & 558.9 & ND & ND & ND & ND \\
\hline Q27 & ND & 354.1 & 40 & 951.1 & ND & 8 & 0 \\
\hline Q28 & 110.5 & 924.9 & 57 & 495.5 & 8 & 16 & 1 \\
\hline
\end{tabular}

$\mathrm{Nd}$ : not determined. The $\mathrm{IC}_{50}$ value was calculated using the non-linear regression obtained by OriginPro 7.0. 


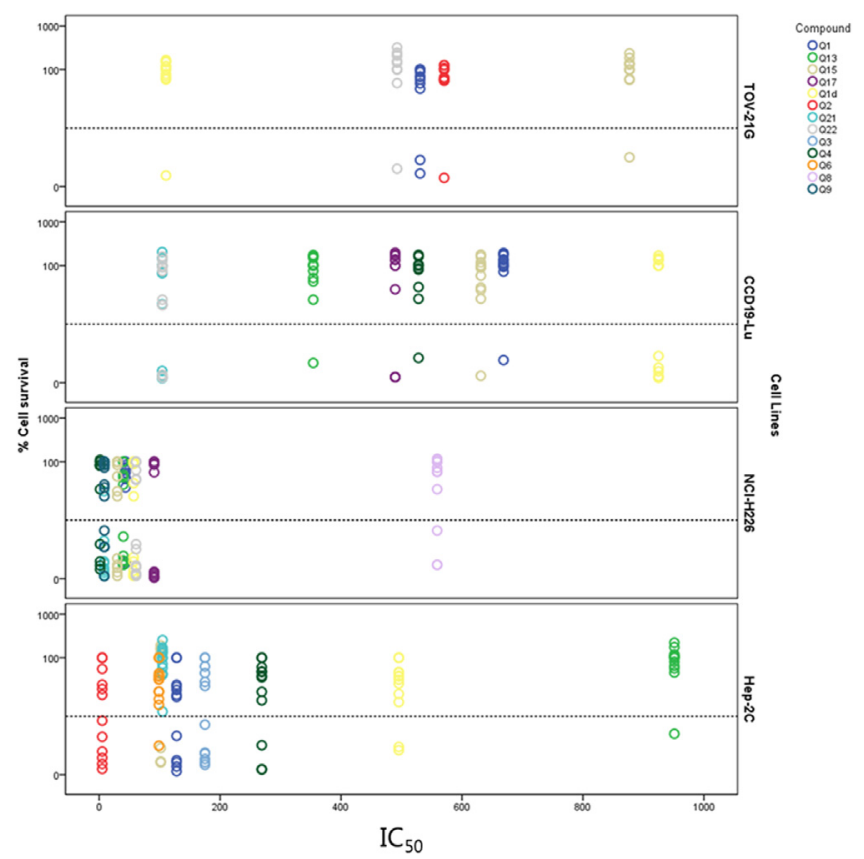

Fig. 6. Association between $\mathrm{IC}_{50}$ values and viability of human tumor cells (Tov21G, Hep2 and NCI-H226) and non-tumor cells (CCD19-Lu). The dotted lines show the $50 \%$ survival limit, in which values are under these lines are indicative of compound cytotoxicity. Compounds whose data are under the dotted line are considered the most promising antitumor agents.

in this cancer type. Interestingly, $\mathbf{Q 1}$ and $\mathbf{Q} 3$ were not cytotoxic against $\mathrm{NCI}-\mathrm{H} 226$, suggesting that there are different biological pathways between them. The Hep2c line was susceptible to the majority of compounds as was NCI-H226, but not in a selective manner. The results for these cells were meaningless once it was shown to be a HeLa-contaminated cell line.

The quinoline with lower $\mathrm{IC}_{50}$ values was the one containing a 4-methoxyphenyl group, which indicates that methoxyl group at 4-position improved the antiproliferative activity against lung cancer. The most effective substituents on tumor cells (except for Hep2c cancer cell line) were 4-fluorophenyl, 4-nitrophenyl, 3nitrophenyl and cyclohexane (Fig. 7). The presence of activating groups on the aromatic ring provided promising anticancer activity.

\subsection{Scavenging of reactive nitrogen species (RNS)}

The ability of the synthesized quinolines to scavenge reactive species with unpaired electrons on nitrogen atoms (RNS) was investigated using the 2,2-diphenyl-1-picrylhydrazyl (DPPH) method. ${ }^{36}$ An initial screening was performed to select potential RNS scavengers. Compounds were tested at $160 \mu \mathrm{M}$ against $100 \mu \mathrm{M}$ DPPH using the plant natural product resveratrol (Resv) as a positive control. Under our experimental conditions, quinolines $\mathbf{Q 1 4}, \mathbf{Q 1 5}, \mathbf{Q 2 1}$ and $\mathbf{Q 2 6}$ were determined to be the best DPPH scavengers because they were able to scavenge $70-85 \%$ of the free radicals. These results are comparable to those obtained for Resv, a known free radical scavenger (Fig. 8). Quinolines Q1, Q2, Q5, Q7, Q13, Q17, Q18 and Q28 were also found to be promising DPPHcapturing compounds; they scavenged free radicals by $45-55 \%$ (Fig. 8). The other quinolines, except for $\mathbf{Q 1 1}$ that was almost inactive, sequestered DPPH by approximately $35-40 \%$ (Fig. 8). Overall, no significant changes were observed in the DPPH scavenging ability for compounds with structural alterations in both the quinoline core and the two phenyl rings. However, some structure-activity relationships can be addressed. For instance, the presence of a

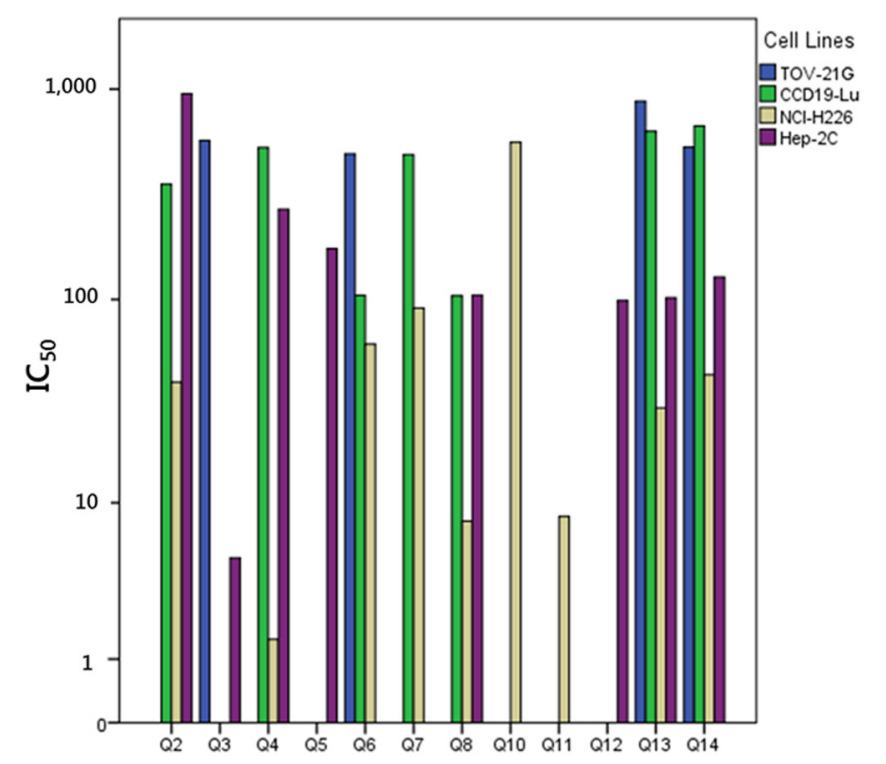

Fig. 7. Values of $\mathrm{IC}_{50}$ for quinolines. The differences among treatments were analyzed by a non-parametric test (Kruskal Wallis; $P<0.05$ ).

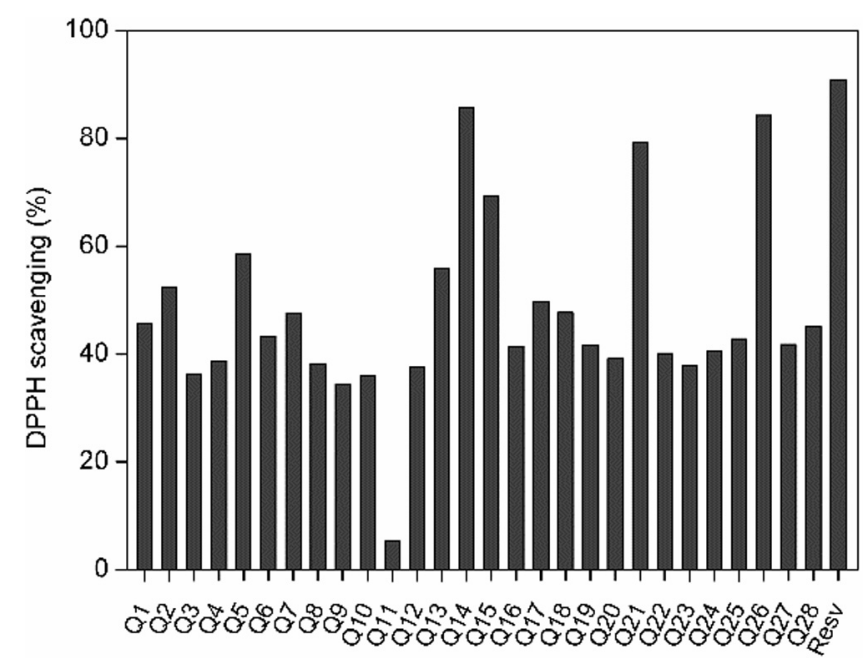

Fig. 8. Potential of quinolines as scavengers of reactive nitrogen species. The reaction medium consisted of the compound tested $(160 \mu \mathrm{M})$ and DPPH radicals $(100 \mu \mathrm{M})$. Resveratrol (Resv) was used as a positive control. Standard deviations (SD) were lower than $28.0 \%$. Data are from three independent experiments, each performed in triplicate.

hydroxyl group at C6 (compound Q15) or C7 (compound Q14) on the quinoline moiety was determined to be essential for scavenging of DPPH. In contrast, a hydroxyl group on the phenyl ring bound to the $\mathrm{C} 2$ of the quinoline core is not mandatory for RNS scavenging, as $\mathbf{Q 1}$ (which is devoid of the corresponding $-\mathrm{OH}$ ) is as effective as compounds $\mathbf{Q 8}$ and $\mathbf{Q 9}$. It is noteworthy that the presence of an $m-\mathrm{NO}_{2}$ group on the phenyl ring bound to the $\mathrm{C} 2$ of the quinoline core compromises the ability of quinoline Q11 to scavenge DPP radicals. Contrary to Q11, Q10, which bears a $p$ $\mathrm{NO}_{2}$ group instead, is able to scavenge DPPH radicals by approximately $40 \%$ (Fig. 8 ).

The concentration of the compound tested necessary to scavenge a free radical by $50 \%$ was determined varying the concentration of quinolines ( $\mathrm{SC}_{50}$; Table 5). Compounds $\mathbf{Q 2 1}$ and $\mathbf{Q 2 6}$ were the most efficient DPPH scavengers, as they exhibited $\mathrm{SC}_{50}$ values lower than $20 \mu \mathrm{M}$. The $\mathbf{Q 1 3}$ was also able to scavenge $50 \%$ of the 
Table 5

Concentrations of promising quinolines that are necessary to scavenge DPPH or $\mathrm{O}_{2}^{-}$ radicals by $50 \%\left(\mathrm{SC}_{50}\right.$ in $\left.\mu \mathrm{M}\right)$.

\begin{tabular}{|c|c|c|}
\hline \multirow[t]{2}{*}{ Compounds } & \multicolumn{2}{|c|}{$\mathrm{SC}_{50}(\mu \mathrm{M})$} \\
\hline & DPPH & $\mathrm{O}_{2}^{-}$ \\
\hline Q1 & $>250.0$ & $>250.0$ \\
\hline Q2 & 180.3 & $>250.0$ \\
\hline Q5 & 197.1 & 104.3 \\
\hline Q6 & 428.1 & $>250.0$ \\
\hline Q7 & 118.5 & $>250.0$ \\
\hline Q9 & $>250.0$ & 121.4 \\
\hline Q13 & 82.7 & $>250.0$ \\
\hline Q15 & $>250.0$ & $>250.0$ \\
\hline Q17 & 104.5 & $>250.0$ \\
\hline Q18 & 260.6 & $>250.0$ \\
\hline Q21 & 19.5 & 220.2 \\
\hline Q23 & $>250.0$ & $>250.0$ \\
\hline Q26 & 18.9 & $>250.0$ \\
\hline Q28 & 168.5 & $>250.0$ \\
\hline Resveratrol (Resv) & 8.2 & 255.0 \\
\hline
\end{tabular}

DPPH present in the reaction medium when applied at $82.7 \mu \mathrm{M}$ (Table 5). The order of increasing potency for the other quinolines is $\mathbf{Q 1 7}>\mathbf{Q 7}>\mathbf{Q 2 8}>\mathbf{Q 2}>\mathbf{Q 5}>\mathbf{Q 1 8}>\mathbf{Q 6}$.

\subsection{Scavenging of reactive oxygen species (ROS)}

A screening was also performed with the synthesized quinolines to evaluate the ability of such compounds to capture the reactive oxygen species (ROS) superoxide anion $\left(\mathrm{O}_{2}^{-}\right)$. Again, quinolines were used at $160 \mu \mathrm{M}$ in a reaction medium in which $\mathrm{O}_{2}^{-}$was artificially generated. Quinolines $\mathbf{Q 5}, \mathbf{Q 8}, \mathbf{Q 9}, \mathbf{Q 1 5}, \mathbf{Q 1 7}, \mathbf{Q 2 0}, \mathbf{Q 2 1}, \mathbf{Q 2 3}$, Q26 and Q27 were much more efficient in the scavenging of ROS than Resv, the positive control (Fig. 9). The efficiency of quinolines Q3, Q4, Q7, Q10, Q12 and Q22 was comparable to that of Resv (Fig. 9). In contrast to the observations with DPPH scavenging, considerable variations in the efficiency of compounds were observed toward $\mathrm{O}_{2}^{-}$. The presence of a $p$-toluyl substituent at $\mathrm{C} 2$ boosted the activity of compound $\mathbf{Q 5}$ compared to the corresponding quinoline that bears a phenyl substituent at this same position (compound Q1). The positive effect observed for Q5 (Fig. 9) is likely due to the presence of benzylic hydrogens, which may favor the formation of benzyl radicals, known to be very stable. Electron-

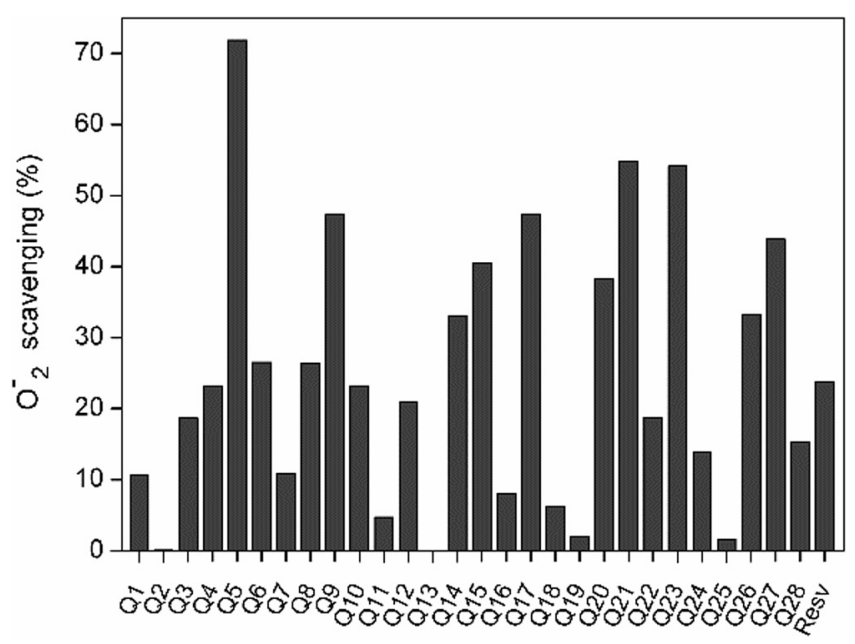

Fig. 9. Effect of quinolines on reactive oxygen species. The reaction medium included artificially-generated superoxide anion $\left(\mathrm{O}_{2}^{-}\right)$and compounds tested at $160 \mu \mathrm{M}$. Resveratrol (Resv) was used as a positive control. Standard deviations (SD) were lower than $17.0 \%$. Data are from three independent experiments, each done in triplicate. withdrawing groups $\left(-\mathrm{NO}_{2}\right.$ and $-\mathrm{CN}$; $\mathbf{Q 1 7}$ and $\mathbf{0 2 1}$, respectively) at $\mathrm{C} 6$ on the quinoline moiety, except for a 3-fluoromethyl group $\left(-\mathrm{CF}_{3} ; \mathbf{Q 1 8}\right)$, increased the activity of quinolines towards $\mathrm{O}_{2}^{-}$ (Fig. 9). In contrast, the presence of electron-withdrawing groups at $\mathrm{C} 7\left(-\mathrm{CO}_{2} \mathrm{H}\right.$ and $-\mathrm{NO}_{2} ; \mathbf{Q 2 2}$ and $\mathbf{Q 2 4}$, respectively) and/or C6 (6-Cl and 7- $\mathrm{CF}_{3} \mathbf{Q 2 5}$ ) negatively affected the potential of quinolines to scavenge $\mathrm{O}_{2}^{-}$species (Fig. 9). The presence of a hydroxyl group $(-\mathrm{OH})$ at $\mathrm{C6}$ (compounds $\mathbf{Q 1 4}$ and $\mathbf{Q 1 5}$ ) contributes to the $\mathrm{O}_{2}^{-}$scavenging activity of quinolines. However, a $m-\mathrm{OH}$ group on the phenyl ring bound to the $\mathrm{C} 2$ of the quinoline core renders the compound twice as active as the one bearing a $p-\mathrm{OH}$ at the same position (Q9 and $\mathbf{Q 8}$, Fig. 9). The quinoline containing a thiomethyl group $\left(-\mathrm{SCH}_{3}\right)$ at $\mathrm{C} 7(\mathbf{Q 2 0})$ was 2 -fold more active than the corresponding derivative bearing an $-\mathrm{OCH}_{3}$ group (Q28) (Fig. 9). The presence of more than one $-\mathrm{OCH}_{3}$ group (compound Q26) or a methylenedioxy (compound Q27), however, boosted the activity of such quinolines toward $\mathrm{O}_{2}^{-}$. Notably, quinoline $\mathbf{Q 2 3}$, which bears a tert-butyl substituent at $\mathrm{C} 6$, was able to scavenge $50 \%$ of the $\mathrm{O}_{2}^{-}$ artificially generated in the medium. All quinolines bearing halogen atoms ( $\mathrm{Br}, \mathrm{F}$ and $\mathrm{Cl}$; Q1, $\mathbf{Q 1 6}$ and Q19, respectively) and unsubstituted phenolic rings demonstrated a lower potential for scavenging ROS ( $<10 \%$ scavenging) (Fig. 9).

The remaining quinolines were found to be poor $\mathrm{O}_{2}^{-}$scavengers (Fig. 9). The most promising quinolines were used further to assess the concentration of compounds necessary to scavenge ROS by $50 \%$ ( $\mathrm{SC}_{50}$ ). Indeed, quinolines $\mathbf{Q 5}$ and $\mathbf{Q 9}$ were twice as potent as Resv towards $\mathrm{O}_{2}^{-}$(Table 5 ).

\section{Conclusions}

A new and efficient method using microwave irradiation and p-sulfonic acid calix[4]arene as catalyst was developed for the synthesis of 28 2,4-disubstituted quinolines. Some advantages of the approach described herein include the use of solvent- and metal-catalyst-free conditions, short reaction times, recycling catalyst besides the catalyst tolerance towards a wide range of functional groups. Quinolines excelled, as they have good to excellent free radical scavenging activity being notable as good antifungal and antiproliferative candidates. The 6-Br-2,4-disubstituted quinolines, in particular, are attractive for use as templates for the development of new antifungal and antitumor agents.

\section{Experimental section}

\subsection{General methods and materials}

All starting materials were obtained from commercially available sources with high-grade purity and were used without further purification. The $p$-sulfonic acid calix[4] arene $\left(\mathrm{CX}_{4} \mathrm{SO}_{3} \mathrm{H}\right)$ was prepared according to known procedures. ${ }^{37}$ Reactions did not require anhydrous conditions. The melting points (uncorrected) of synthesized quinolines were determined using a MQAPF-301 Microquímica micromelting device. Infrared spectra were obtained on a FT-IR Varian 660 Fourier Transform Infrared spectrometer. The ${ }^{1} \mathrm{H}$ and ${ }^{13} \mathrm{C}$ NMR spectra were obtained on a Varian Mercury spectrometry at $300 \mathrm{MHz}$ for ${ }^{1} \mathrm{H}$ and $75 \mathrm{MHz}$ for ${ }^{13} \mathrm{C}$, in $\mathrm{CDCl}_{3}$. Coupling constants $(\mathrm{J})$ are reported in Hertz $(\mathrm{Hz})$. High resolution mass spectra (HRMS) were obtained on a Shimadzu LC-IT-TOF Prominence system.

\subsection{General procedure for the synthesis of 2,4-disubstuted quinolines}

Microwave (MW) approach: A mixture of an aniline (1 mmol), aldehyde $(1.2 \mathrm{mmol})$, styrene $(1.5 \mathrm{mmol})$ and $p$-sulfonic acid calix [4]arene ( $1 \mathrm{~mol} \%$ ) was stirred at $200{ }^{\circ} \mathrm{C}$ for $20 \mathrm{~min}$. 
Conventional heating $(\mathrm{CH})$ : A mixture of an aniline $(1 \mathrm{mmol})$, aldehyde (1.2 mmol), styrene (1.5 mmol), $p$-sulfonic acid calix[4] arene and acetonitrile ( $1 \mathrm{~mol} \%$ ) was stirred at $80^{\circ} \mathrm{C}$ for $12 \mathrm{~h}$.

Treatments ( $\mathrm{MW}$ and $\mathrm{CH}$ ): The reaction was quenched by addition of water $(10 \mathrm{~mL})$ and the product was extracted with dichloromethane $(3 \times 10 \mathrm{~mL})$. The solvent was removed under reduced pressure in a rotary evaporator. The obtained solid was obtained was purified by silica gel column chromatography (hexane/dichloromethane/acetone, 8:2.8:0.1) to afford the quinolines Q1-Q28 in high purity (Fig. 1). All quinolines were characterized by ${ }^{1} \mathrm{H}$ and ${ }^{13} \mathrm{C}$ NMR, IR, HRMS (ESI) and melting points.

\subsection{Antifungal activity}

\subsubsection{Microorganisms and media}

For the evaluation of antifungal activity, standardized strains of C. albicans ATCC 10231 and C. neoformans ATCC 32264 from the American Type Culture Collection (ATCC, Rockville, MD, USA) were used. Strains were grown on Sabouraud-chloramphenicol agar slants for $48 \mathrm{~h}$ at $30^{\circ} \mathrm{C}$ and then maintained on slopes of Sabouraud-dextrose agar (SDA, Oxoid). Strains were sub-cultured every 15 days to prevent pleomorphic transformations. Inocula were obtained according to reported procedures ${ }^{38}$ and adjusted to $1-5 \times 10^{3}$ colony forming units $(\mathrm{CFU}) / \mathrm{mL}$.

\subsection{Fungal growth inhibition}

Yeasts broth microdilutions (technique M27-A3 of CLSI) were performed in 96-well microtiter plates. For the assay, compoundtest wells (CTWs) were prepared with stock solutions of each compound in DMSO (concentration $\leqslant 1 \%$ ) and diluted with RPMI-1640 to final concentrations in the range from 3.9 to $250.0 \mu \mathrm{g} \mathrm{mL}^{-1}$. An inoculum suspension $(100 \mu \mathrm{L}$ ) was added to each well (final volume in the well $=200 \mu \mathrm{L}$ ). A growth control well (GCW) (containing medium, inoculum and the same amount of DMSO used in a CTW) and a sterility control well (SCW) (sample, medium and sterile water) were included for each fungus tested. Microtiter trays were incubated in a moist, dark chamber at $30^{\circ} \mathrm{C}$ for $48 \mathrm{~h}$ for both yeasts. Microtiter plates were read in a VERSA Max microplate reader (Molecular Devices, Sunnyvale, CA, USA). Amphotericin B was used as a positive control. Tests were performed in triplicate. Reduction of growth for each compound concentration was calculated as it follows: \% inhibition $=100-($ OD 405 CTW - OD 405 SCW $) /($ OD 405 GCW - OD 405 SCW). The means \pm standard deviations (SD) were used for plotting dose-response curves representing \% inhibition versus concentration of each compound using SigmaPlot 11.0 software.

\subsection{1. $M I C_{80}$ and $M I C_{50}$ determinations}

Two endpoints were defined from the experiments described above. Minimum Inhibitory Concentrations $80\left(\mathrm{MIC}_{80}\right)$ and 50 $\left(\mathrm{MIC}_{50}\right)$ were defined as the minimum concentration that inhibits $80 \%$ or $50 \%$ of the fungal growth, respectively.

\subsection{Antiproliferative assay}

Human tumor cell lines CCD-19Lu $\left(\right.$ ATCC $^{\circledR}$ CCL-210 $\left.^{\mathrm{TM}}\right)$, WI-26 VA4 (ATCC ${ }^{\circledR}$ CCL-95. $^{\text {TM }}$ ), HEp-2C $\left(\right.$ ATCC $^{\circledR}$ CCL-23 $^{\text {TM }}$ ) and NCI-H226 (ATCC $^{\circledR}$ CLR-5826 ${ }^{\mathrm{TM}}$ ) were cultured in MEN-NEA, EMEM and RPMI media, respectively (Sigma-Aldrich Co. LLC.) supplemented with $10 \%$ foetal bovine serum and $1 \%$ L-glutamine in a $37^{\circ} \mathrm{C}$ humid atmosphere enriched with $5 \% \mathrm{CO}_{2}$. Cells were culture on 96 well plates $(1 \times 105$ cells/well $)$ in the presence or absence of synthesized quinolines at concentration in the range from 1.0 to $1000 \mu \mathrm{g} \mathrm{mL}^{-1}$. After $24 \mathrm{~h}$, the samples were sensitized in a MTT assay, and their absorbances (at $540 \mathrm{~nm}$ ) measured $3 \mathrm{~h}$ later using a Molecular Devices Spectramax M5E. Values, corresponding the cell viability, were used to calculate the $\mathrm{IC}_{50}$ values for statistical analysis purposes.

\subsection{Scavenging of reactive nitrogen species}

The ability of quinolines Q1-Q28 to scavenge a 2,2-diphenyl-1picrylhydrazyl (DPPH) radical, a reactive nitrogen species (RNS), was determined according to Gülcin, ${ }^{39}$ with modifications. The screening of potential candidates was performed by incubating each compound-test $\left(200 \mu \mathrm{g} \mathrm{mL}^{-1}\right)$ in an ethanolic medium containing $100 \mu \mathrm{M}$ DPPH. The systems were maintained under stirring and absence of light for $30 \mathrm{~min}$ and the absorbance was measured at $517 \mathrm{~nm}$. Those compounds with potential scavenging activities were then tested in the range from 0 to $160 \mu \mathrm{g} \mathrm{mL}^{-1}$ to determine the concentration necessary to scavenge DPPH radicals by $50 \%$ $\left(\mathrm{IC}_{50}\right)$. The results presented are from three independent experiments, each performed in triplicate.

\subsection{Scavenging of reactive oxygen species}

The capacity of quinolines to scavenge superoxide anions $\left(\mathrm{O}_{2}^{-}\right)$ was evaluated in $50 \mathrm{mM}$ phosphate buffer ( $\mathrm{pH} 7.8)$ containing $13 \mathrm{mM}$ L-methionine, $75 \mu \mathrm{M}$ nitroblue tetrazolium, $100 \mu \mathrm{M}$ EDTA, $2 \mu \mathrm{M}$ riboflavin and compound-test at $0-200 \mu \mathrm{g} \mathrm{mL}^{-1}$. Reaction mixtures were incubated for $10 \mathrm{~min}$ at $25{ }^{\circ} \mathrm{C}$ in the presence of fluorescent light to induce $\mathrm{O}_{2}^{-}$formation. Controls consisted of reaction mixtures maintained at $25^{\circ} \mathrm{C}$ for $10 \mathrm{~min}$ in the absence of light. The percentage of $\mathrm{O}_{2}^{-}$scavenged by each compound-test was determined at $575 \mathrm{~nm}$. The results presented are from three independent experiments, each performed in triplicate.

\section{Acknowledgements}

Authors are thankful for the financial support provided by Fundação de Amparo à Pesquisa do Estado de Minas Gerais - Brazil (FAPEMIG), Conselho Nacional de Desenvolvimento Científico e Tecnológico - Brazil (CNPq) and Coordenação de Aperfeiçoamento de Pessoal de Nível Superior - Brazil (CAPES). AdF, LVM and SAF are supported by Research Fellowships from CNPq and MD is a member of the CONICET Researcher Career. SZ acknowledges ANPCyT PICT 20141170.

This work was supported by the National Program for Academic Cooperation (PROCAD) of CAPES/Brazil.

\section{A. Supplementary material}

Supplementary data associated with this article can be found, in the online version, at http://dx.doi.org/10.1016/j.bmc.2016.12.023.

\section{References}

1. (a) Bernotas RC, Singhaus RR, Kaufman DH, et al. Bioorg Med Chem Lett. 2010;20:209-212;

(b) Vandekerckhove S, D'Hooghe M. Bioorg Med Chem. 2015;23:5098-5119; (c) Jones RA, Panda SS, Hall CD. Eur J Med Chem. 2015:97:335-355;

(d) Chung P-Y, Bian Z-X, Pun H-Y, et al. Future Med Chem. 2015;7:947-967;

(e) Afzal O, Kumar S, Haider MR, et al. Eur J Med Chem. 2015;97:871-910;

(f) Bharate JB, Vishwakarma RA, Bharate SB. RSC Adv. 2015;5:42020-42053.

2. (a) Patel SR, Gangwal R, Sangamwar AT, Jain R. Eur J Med Chem. 2015;93:511-522;

(b) Patel SR, Gangwal R, Sangamwar AT, Jain R. Eur J Med Chem. 2014;85:255-267.

3. (a) Rossiter S, Péron JM, Whitfield PJ, Jones K. Bioorg Med Chem Lett. 2005;15:4806-4808;

(b) Fournet A, Vagneur B, Richomme P, Bruneton J. J Chem. 1989;67:2116-2118.

4. Devakaram R, Black D StC, Kumar N. Tetrahedron Lett. 2012;53:2269-2272.

5. (a) Vandekerckhove S, Herreweghe SV, Willems J, et al. Eur J Med Chem. 2015;92:91-102; 
(b) Vandekerckhove S, Tran HG, Desmet T, D'hooghe M. Bioorg Med Chem Lett. 2013:23:4641-4643.

6. Almansour AI, Arumugam N, Kumar RS, et al. Tetrahedron Lett. 2015;49:6900-6903.

7. El-Damasy AK, Seo SH, Cho N-C, et al. Eur J Med Chem. 2015;101:754-768.

8. Koh EJ, Gamal MIE, Oh C, et al. Eur J Med Chem. 2013;70:10-21.

9. Savegnago L, Vieira AI, Seus N, et al. Tetrahedron Lett. 2013;1:40-44.

10. Xi GL, Liu ZQ. Eur J Med Chem. 2014;86:759-768.

11. Greeff J, Joubert J, Malan SF, Dyk S. Bioorg Med Chem. 2012;2:809-818.

12. (a) Sandelier MJ, de Shon P. Org Lett. 2007;9:3209-3212;

(b) Korivi RP, Cheng CHJ. Org Chem. 2006;71:7079-7082;

(c) Arcadia A, Marinelli F, Rossi E. Tetrahedron. 1999;55:13233-13250;

(d) Devakaram R, Black DS, Kumar N. Tetrahedron Lett. 2012;53:2269-2272;

(e) Tang J, Wang L, Mao D, et al. Tetrahedron. 2011;67:8465-8469;

(f) Cao K, Zhang FM, Tu YQ Zhuo XT, Fan CA. Chem Eur J. 2009;15:6332-6334;

(g) Rotzoll S, Willy B, Schönhaber J, Rominger F, Müller TJJ. Eur J Org Chem. 2010;18:3516-3524.

13. (a) Simões JB, de Fátima A, Sabino AA, Barbosa LCA, Fernandes SA. RSC Adv. 2014;4:18612-18615;

(b) Kulkarni A, Török B. Green Chem. 2010;12:875-878.

14. Povarov LS. Russ Chem Rev. 1967;36:656-670.

15. Batey RA, Simoncic PD, Lin D, Smyj RP, Lough AJ. Chem Commun. 1999;651-652.

16. Xia M. Lu Y. Synlett. 2005;2357-2361.

17. Suresh R, Muthusubramanian S, Senthilkumaran R, Manickam G. J Org Chem. 2012;77:1468-1476.

18. More SV, Sasty MNV, Yao C-F. Synlett. 2006:1399-1403.

19. Richter H, Mancheño OG. Org Lett. 2011;13:6066-6609.

20. De K, Legros J, Crousse B, Chandrasekaran S, Bonnet-Delpon D. Org Biomol Chem. 2011;9:347-350.

21. Chen L, Li C-J. Green Chem. 2003;5:627-629.

22. Kumar A, Srivastava S, Gupta G, Chaturvedi V, Sinha S, Srivastava R. ACS Comb Sci. 2011;13:65-71.

23. Huang Y, Oiu C, Li Z, et al. ACS Sustain Chem Eng. 2016;4:47-52.

24. (a) de Assis JV, Abranches PAS, Braga IB, et al. RSC Adv. 2016;6:24285-24289; (b) Palermo V, Sathicq A, Liberto N, et al. Tetrahedron Lett. 2016;57:2049-2054; (c) Rego YF, da Silva CM, da Silva DL, et al. Arabian J Chem. 2016. http://dx.doi. org/10.1016/i.arabjc.2016.04.007;

(d) Borel CR, Barbosa LCA, Maltha CRA, Fernandes SA. Tetrahedron Lett. 2015;56:662-665;

(e) da Silva DL, Terra BS, Lage MR, et al. Org Biomol Chem. 2015:13:3280-3287;

(f) Natalino R, Varejão EVV, da Silva MJ, Cardoso AL, Fernandes SA. Catal Sci Technol. 2014;4:1369-1375;

(g) Simões JB, da Silva DL, de Fátima A, Fernandes SA. Curr Org Chem. 2012;16:949-971;

(h) Fernandes SA, Natalino R, da Silva MJ, Lima CF. Catal Commun. 2012;26:127-131;

(i) Fernandes SA, Natalino R, Gazolla PAR, da Silva MJ, Jham GN. Tetrahedron Lett. 2012;53:1630-1633;

(j) da Silva DL, Fernandes SA, Sabino AA, de Fátima A. Tetrahedron Lett. 2011;52:6328-6330.
25. Simões JB, de Fátima A, Sabino AA, et al. Org Biomol Chem. 2013;11:5069-5073.

26. (a) Kumar M, Kaur T, Gupta VK, Sharma A. RSC Adv. 2015;5:17087-17095;

(b) Cheng XM, Liu XW. J Comb Chem. 2007;9:906-908;

(c) Yang X, Odelius K, Hakkarainen M. ACS Sustain Chem Eng. 2014;2:2198-2203;

(d) Spencer J, Baltus CB, Patel H, et al. ACS Comb Sci. 2011;13:24-31;

(e) Mehta VP, Sharma A, der Eycken EV. Org Lett. 2008;10:1147-1150;

(f) Anasta PT, Warner JC. Green Chemistry: Theory and Practical. USA: OUP; 2000.

27. (a) Sashidhara KV, Palnati GR, Singh LR, et al. Green Chem. 2015;17:3766-3770; (b) Galvez J, Castillo J-C, Quiroga J, Rajzmann M, Rodriguez J, Coquerel Y. Org Lett. 2014;16:4126-4129;

(c) Kulkarni AR, Thakur GA. Tetrahedron Lett. 2013;54:6592-6595;

(d) Thakur GA, Kulkarni AR, Deschamps JR, Papke RL. J Med Chem. 2013;56:8943-8947;

(e) Mert-Balci F, Imrich H-G, Conrad J, Beifuss U. Helv Chim Acta. 2013;96:1681-1692;

(f) Roy S, Reiser O. Angew Chem Int Ed. 2012;51:4722-4725;

(g) Chen C-H, Yellol GS, Lin P-T, Sun C-M. Org Lett. 2011;13:5120-5123;

(h) Astudillo LS, Gutierrez M, Gaete H, et al. Lett Org Chem. 2009;6:208-212;

(i) Xing XL, Wu JL, Dai WM. Tetrahedron. 2006;62:11200-11206;

(j) Duvelleroy D, Perrio U, Parisel O, Lasne MC. Org Biomol Chem. 2005;3:3794-3804.

28. Kouznetsov VV. Tetrahedron. 2009;65:2721-2750.

29. Martínez JJ, Nope E, Rojas H, Brijaldo MH, Passos F, Romanelli G. J Mol Catal A: Chem. 2014;392:235-240.

30. (a) Mathew B, Nath M. ChemMedChem. 2009;4:310-323.

(b) Chen S, Playford E, Sorrell T. Curr Opin Pharmacol. 2010;10:522-530;

(c) Butts A, Krysan D. PLoS Pathog. 2012;8:e1002870.

31. (a) Kouznetsov V, Meléndez GC, Derita M, Svetaz L, del Olmoa E, Zacchino SA Bioorg Med Chem. 2012;20:6506-6512;

(b) Vargas L, Zacchino SA, Kouznetsov VV. J Braz Chem Soc. 2010;21:105-111; (c) Meléndez C, Kouznetsov V, Sortino M, Álvarez S, Zacchino SA. Bioorg Med Chem. 2008;16:7908-7920.

32. Pfaller MA, Diekema DJ. Clin Microbiol Rev. 2007;20:133-163.

33. Trpković A, Pekmezović M, Barać A, Radović LC, Arsenijević VA. J Mycol Med 2012;22:243-248.

34. Ernst EJ, Roling EE, Petzold CR, Keele DJ, Klepser ME. Antimicrob Agents Chemother. 2002;46:3846-3853.

35. Mahavorasirikul W, Viyanant V, Chaijaroenkul W, Itharat A, Na-Bangchang K BMC Complement Altern Med. 2010:10:55-62.

36. da Silva DL, Reis FS, Muniz DR, et al. Bioog Med Chem. 2012;20:2645-2650.

37. (a) Gutsche CD, Dhawan B, No KH, Muthukrishnan R. J Am Chem Soc. 1981;103:3782-3792;

(b) Casnati A, Ca ND, Sansone F, Ugozzoli F, Ungaro R. Tetrahedron. 2004;60:7869-7876:

(c) Shinkai S, Araki K, Tsubaki T, Some T, Manabe O. J Chem Soc Perkin Trans 1987;1:2297-2299.

38. CLSI document M27-A3, 3rd ed. Vol 28. Wayne, PA: Clinical and Laboratory Standards Institute; 2008: 1-25.

39. Gülçin I. Innovat Food Sci Emerg Tech. 2010;11:210-218. 